Article

\title{
On the System. Boundary Choices, Implications, and Solutions in Telecoupling Land Use Change Research
}

\author{
Cecilie Friis ${ }^{1,2, *}$ and Jonas Østergaard Nielsen ${ }^{1,2}$ \\ 1 IRI THESys, Humboldt-Universität zu Berlin, Unter den Linden 6, 10099 Berlin, Germany; \\ jonas.ostergaard.nielsen@hu-berlin.de \\ 2 Geography Department, Humboldt-Universität zu Berlin, Unter den Linden 6, 10099 Berlin, Germany \\ * Correspondence: cecilie.friis@hu-berlin.de
}

Academic Editor: Helmut Haberl

Received: 24 March 2017; Accepted: 1 June 2017; Published: 7 June 2017

\begin{abstract}
Land-based production provides societies with indispensable goods such as food, feed, fibre, and energy. Yet, with economic globalisation and global population growth, the environmental and social trade-offs of their production are ever more complex. This is particularly so since land use changes are increasingly embedded in networks of long-distance flows of, e.g., material, energy, and information. The resulting scientific and governance challenge is captured in the emerging telecoupling framework addressing socioeconomic and environmental interactions and feedbacks between distal human-environment systems. Understanding telecouplings, however, entails a number of fundamental analytical problems. When dealing with global connectivity, a central question is how and where to draw system boundaries between coupled systems. In this article, we explore the analytical implications of setting system boundaries in the study of a recent telecoupled land use change: the expansion of Chinese banana plantation investments in Luang Namtha Province, Laos. Based on empirical material from fieldwork in Laos in 2014 and 2015, and drawing on key concepts from the 'systems thinking' literature, we illustrate how treating the system and its boundaries as epistemological constructs enable us to capture the differentiated involvement of actors, as well as the socio-economic and environmental effects of this land use change. In discussing our results, the need for more explicit attention to the trade-offs and implications of scale and boundary choices when defining systems is emphasised.
\end{abstract}

Keywords: telecoupling; land use change; land systems; coupled human-environment systems; system boundaries; scale; Laos; China; banana plantations

\section{Introduction}

Economic globalisation, urbanisation, and global environmental change have accelerated the pressures on land resources and increased the complexity of land system change around the world [1-5]. A prominent feature of these processes is the intensified interconnectedness between the places that supply land-based products and the places that demand them. Recently, conceptualised as telecouplings in the field of coupled human-environment systems research and Land System Science (LSS) [6,7], the socioeconomic and environmental interactions creating this connectedness have been recognised as a substantial sustainability and equity challenge [8-13]. In particular, it has been noted that telecouplings are prone to creating landscapes of extraction and exploitation [14], and a number of recent studies indicate how telecouplings increase existing or create new livelihood vulnerabilities $[15,16]$, as well as accentuate inequalities in the access to, control over, and benefits from land and other natural resources [17-19]. As a result, discussions on the need for a better understanding of the differentiated effects of telecoupling have arisen, as has the recognition of the need to identify leverage points for intervention towards more sustainable land outcomes $[8,9,12,20]$. 
A prerequisite for such endeavours is building a better understanding of how telecouplings influence land use change outcomes. A framework has been proposed, defining telecouplings as cross-scalar, networked, and complex socioeconomic and environmental interactions between two or more distant and distinct coupled human-environment systems [6,7]. The framework presents a tool for describing and characterising telecouplings by classifying sending, receiving, and spill-over systems, and flows between these systems, as well as the agents, causes, and effects within them [6]. This framework offers an analytical breakdown of the interconnectivity in global land use change by establishing manageable units of analysis, most notably 'systems' and 'flows', and making it possible to avoid a 'holistic trap' were everything gets connected to everything else. However, it also includes a fundamental analytical challenge regarding system boundaries. How to define and understand systems as separate coupled human-environment systems rather than one larger integrated system in a globalised world is consequently emerging as a key challenge in telecoupling research [7,21,22].

Place-based definitions of system boundaries are most commonly used. Liu, et al. [23] assert, for example, that the framework treats "each place as a coupled human and natural system, in which humans and natural components interact not only locally but also across temporal and spatial scales" [23] (p. 1). Studies employing the framework have so far focused on linkages related to specific land uses, sectors, or other natural resources such as soybean and beef production or conservation and water use in places separated by large geographical or functional distances, where the latter is 'measured' in terms of territorial governance structures, for example, administrative regions or nation states (e.g., [18,24-27]). While such system boundaries are useful for telecoupling analysis concerned with, for example, trade or material flows, treating systems as spatially discrete places risks presenting them as endogenous wholes, where the differentiated distribution of costs and benefits, as well as the agency among and between actors, are "black-boxed". Moreover, the complexity of social and ecological processes involved in creating telecouplings challenges the separation of systems with place-based logics due to, among other things, spatiotemporal scale mismatches between the social and ecological processes embedded in the coupled system [28]. For land system change specifically, the difficulty arises partly in the fact that while land as a resource is always located in geographic and territorial space, the actors and causal processes influencing the use of land can, but may not, be located in the same place [29]. For dealing with the potential (adverse) effects of telecouplings, there is therefore a need in LSS to move beyond "the tendency to view actions primarily within clear politically or ecologically bounded systems" [7] (p. 153). Accordingly, Eakin, et al. [7] have suggested a moderation of the boundary definition for telecoupling research by including "the potentially aspatial social networks, institutions, and governance structures that directly influence those [place-based human-environment] interactions" (p. 142) in the system.

Applying this system boundary definition in telecoupling analysis, however, requires a flexible and heuristic approach to the system; one that leaves the question of boundaries open for empirical investigation rather than imposing them as a given geographical entity or administrative unit. Here, the contemporary systems thinking literature provides useful perspectives [20,30,31]. Emphasising a distinction between an ontological and an epistemological approach to systems analysis, this literature offers insights directing attention to an understanding of systems as 'epistemological constructs' as opposed to 'ontological entities', e.g., places and regions as 'real' systems. Approaching land systems as epistemological constructs enables researchers to define the 'system of interest' and consider scale and boundary choices based on what and who the object of study is. As such, it allows for a reflexive approach to systems analysis that opens telecoupling research up to more social constructivist modes of research [32].

In this paper, we take up these perspectives in relation to the case of a telecoupled land use change in Luang Namtha Province, the Lao People's Democratic Republic (Lao PDR or Laos), namely a rapid and widespread conversion of lowland paddy rice cultivation to mono-cropped banana plantations driven by Chinese investors producing banana for the Chinese fresh-fruit market (An in-depth analysis of the telecouplings influencing this land use change is presented elsewhere [33]). We begin by elaborating on the theoretical perspectives of approaching systems as epistemological constructs in 
telecoupling and land use change research. After a brief introduction of the methods and the empirical setting, we present the banana land system. Rather than defining the system as a place, e.g., the village or the region were banana cultivation is taking place, we start from two banana plantations in a rural community in Luang Namtha Province and construct our 'system of interest' around the specific land use change and the network of actors and government institutions that are influencing it. Doing so enables a system analysis that incorporates the actors mediating flows and interactions with other systems, independent of their 'position' in geographical space. Moreover, it opens up for understanding the uneven distribution of both direct and indirect positive and negative effects of the banana land use change, as only part of the community is included in the banana schemes. This highlights the risk of place-based system conceptions for masking differentiated outcomes of telecoupling, even at a very small geographical scale such as a village in northern Laos. In the discussion, we use these insights to push for a more integrative and reflexive approach to system thinking in telecoupling research, especially when aiming for the identification of leverage points of change and intervention for more sustainable land use change.

\section{Theoretical Background}

That various manifestations of globalisation have caused a spatial decoupling of land use changes from their most important driving forces is increasingly acknowledged in LSS [34-38]. Efforts have therefore gone into conceptualising the distal drivers of change and developing new and more integrated approaches equipped for bridging 'classical' place-based analysis with more processual approaches $[3,39]$. The telecoupling framework is gaining momentum as a starting point for such endeavours as it explicitly addresses distant flows, processes, and feedbacks, without abandoning place-based land system analysis $[6,24,26,33,40-42]$. Specifically, the telecoupling framework integrates two approaches to the study of human-environment interactions. First, it draws on the conceptual framework of coupled human-environment systems [43,44], social-ecological systems [45-48] or coupled human and natural systems (CHANS) [49], and offers a spatial extension of this framework by highlighting the distant interactions between systems [6]. Coupled systems are conventionally understood as complex entities composed of socioeconomic and biophysical elements that interact and shape each other in dynamic, nonlinear, and emergent ways $[8,49,50]$. For the study of land use change, land systems are specifically conceptualised as the terrestrial components of the Earth System, where land use activities and the potential environmental and ecosystem feedbacks that influence such activities make up the coupling between the human and the environmental subsystem [51,52]. As such, land systems are understood as place-based coupled systems spanning from local landscapes to global regions in a nested spatial hierarchy that requires the analysis of different spatial and temporal resolutions [2]. By building on these notions and further categorising systems as sending, receiving, or spill-over systems [6], the telecoupling framework presents a way for land system analysts to deal with global interconnectivity by breaking it down into tractable units of analysis.

Second, the framework opens up the coupled system approach to more processual and networked understandings of human-environment changes by focusing attention on "the processes and causal chain[s] that links land parcels to land systems, to actors and actor networks, to institutions and governance, and ultimately to other land systems and places" [7] (p. 153). Drawing on well-established concepts in human geography and the wider social sciences that posits place and space as relational concepts [53-55], this process-oriented component of telecoupling analysis is proposed in response to a number of challenges with a place-bounded and spatially nested conception of systems [22,56]. Chief among these are inherent scale-mismatches in the spatial and temporal dimensions of the human/social and the natural/ecological components of coupled systems [28,57]. Social processes and actor networks, for example, almost always extend beyond the physical boundaries of a natural resource area [58], or an environmental problem may overflow the scope and authority of existing institutional management structures [59,60]. Furthermore, the processes of economic, social, and cultural connections and distinctions that operate between individuals or groups in a society maintain or 
create social spaces, understood as spaces where people, who are physically distant, can be socially close, and vice-versa $[53,55]$. An example is diasporic communities separated by a large Euclidian space, but maintaining social connections that transcend physical distances. As such, spatially distant communities can influence land use decisions "back home" (e.g., [61-63]). Similarly, examples of local socioeconomic distinctions imposed on communities when some people are incorporated into large-scale agro-business production, while others are left out, illustrate how being physically close does not equate to being socially connected (e.g., [64-66]). The (almost global) dispersal of information and communication technologies underpins these connection and distinctions and contributes to both shrinking and increasing social distances. Finally, the hierarchical and nested understandings of spatial scales in much land system science have been criticised for risking a conflation of scale with agency [22]-i.e., 'local actors' are privileged in relation to 'local' processes and 'global actors' in relation to 'global' processes with an implicit assumption about their abilities and power to influence change at those 'scales' [53]. This produces a power asymmetry between, for example, 'local' and 'global' actors, that can blur the complexity of interactions and reproduce preconceived ideas of the distribution of power, rather than opening these up to empirical investigation. Others have noted the risk of a "scaling parsimony", where causal explanations are viewed as more plausible when the drivers and outcomes of change are 'observed' at the same spatial level [67]. In emphasising networked relations between people and places, the telecoupling framework moves beyond such scale conceptions and focuses attention on the cross-scale processes that connect and create telecoupled systems.

A main strength of the telecoupling framework is therefore that it aims to integrate systemic and processual approaches to human-environment interactions. However, a fundamental tension between the two perspectives exists, most notably in the need for delineating systems as 'distant' and 'separated', which is a necessary part of the analytical categorisation of sending, receiving, and spill-over systems. The conception of systems advocated by Liu, Eakin and colleagues has mainly dealt with this challenge by focusing attention on geographical or institutional 'distance' $[6,7,11]$. This approach has its strength in allowing researchers to set system boundaries a priori and use, for example, administrative units as system boundaries in multi-region input-output analysis $[68,69]$ or in studies discussing the scope and limitation of national and regional governance for managing telecouplings [9]. However, for empirical studies seeking to explore the influence and outcomes of telecouplings in particular locations, such system boundaries risk masking the complexity and fluidity of the social-ecological relations that are precisely the focus of telecoupling research.

Contemporary systems thinking offers interesting ways to deal with this challenge. A system has been defined in many ways within this literature, but it is fundamentally understood as "a whole whose elements are 'interconnected'" [70] (p. 140), and whose key property "the boundary with its environment, is of particular epistemological import, since it defines the closure commonly deemed to be a necessary part of scientific enquiry" [71] (p. 1331). As such, a system can be a thing-an entity exhibiting connectivity, but it can also be a process-a way of thinking about the connections between things [30,70]. Beyond this basic understanding, systems thinking is dominated by two approaches, described as 'hard' and 'soft' systems thinking [70,72] or 'ontological' and 'epistemological' systems approaches [20]. The 'hard' ontological perspective posits systems as 'real-world entities' and system models as representations of the world [70], resonating with conventional system thinking in LSS and coupled human-environment systems science in general $[73,74]$. In contrast, the 'soft' epistemological tradition views systems as heuristic tools that are defined "by the subjective interest and pre-analytic assumptions of the researcher, with all the potential problems this entails" [20] (p. 3). System models are seen as intellectual constructs embedded with analytical choices and trade-offs. Because the relevant spatial and temporal scale of a system is understood as contingent rather than given by any 'natural' extent or resolution, systems research with an epistemological approach is about defining and isolating "what is of interest and exclud[ing] what is not" [71] (p. 1325). Describing a system is thus an analytical operation in itself, an intermediary step that frames a given human-environmental issue in a particular way and setting system boundaries becomes a matter of analytical perspective, as opposed to something determined 
by either distance or governance structure. An epistemological system approach therefore allows telecoupling analysis to capture both place-based interactions and actor networks in the system.

Interdisciplinary studies in the LSS literature have made similar efforts to integrate actor networks and tackle diverse governance arrangements for land change by engaging with, for example, the Global Production Network (GPN) framework (e.g., [75-77]) and with multi-level or polycentric governance analysis (e.g., $[8,9,78])$. Such approaches present telecoupling research with the means to deal with connectivity between distant actors and outcomes in land systems, as well as their social, institutional, and territorial embeddedness in transnational production networks [21]. However, what the ideas from systems thinking, and in particular an epistemological systems analysis, bring to these discussions is explicitly giving up the notion that distal flows and processes 'act into' existing and naturally occurring human-environment systems (or places). Yet, it does allow telecoupling research to use systems as artificial units of analysis. Acting "as if" a spatial entity or interaction was a 'real' observable system is useful for certain types of research [70], and opens up for investigating what type of knowledge is produced if a country, a city, or a region is framed as a human-environment system. What is crucial, however, is the explicit awareness of how and why certain analytical scale and boundary choices are made, by the actors 'engaged' in creating the system and by the researchers concerned with understanding it, and with what trade-offs and limitations. Moving from coupled human-environment systems as 'natural entities' to analytical constructs does not mean, though, that boundaries or scales are purely "arbitrary constructs of the researcher" with no relation to the phenomena, changes, networks, and processes analysed or the questions posed [79] (p. 36). Rather, it signifies that the position and interest of a researcher (or any other actor with a stake in constructing a system) influences and structures the way in which a given system is defined and understood, and thus that multiple systems can be 'formulated' in any place at different spatial, ecological, and social scales. Adopting an epistemological system approach thus opens up telecoupling research, and potentially the wider field of land system science, to more constructivist modes of knowledge production that enable a deeper engagement with discussions and concepts from the social sciences, among other things regarding the construction of social space and place [32,53]. In light of new land use change research that emphasises how "looping effect[s] exists between choice of scale, problematization of land use competition, actual land use change and interventions into land use" [80,81] (p. 11), such engagement is highly relevant and needed.

\section{Methods}

Thinking about human-environment systems as epistemological constructs enables a flexible and empirical approach to the challenge of defining systems and system boundaries. For illustrating and discussing how these perspectives contribute to an empirical telecoupling analysis, we consider the case of banana plantation expansion in a small rural village, Ban Sirimoon, in Luang Namtha Province, Laos (Figure 1). Largely driven by Chinese investments and with a solely export-oriented production, the banana plantations can be conceptualised as a telecoupled land system with a strong spatial and institutional decoupling between the drivers and outcomes of land use change. By working progressively 'outwards' in time and space, we traced the actors involved, their relations and interaction, and the (distal) flows involved in the banana boom as a way of defining the 'banana land system' (see $[82,83])$.

Our case study builds on empirical material collected during seven months of fieldwork in the village and Luang Namtha Province in April-May and August-December 2014, as well as June 2015. The methods included participant observation, informal conversations in the village, and a household questionnaire survey with the heads of households (48 out of 66), providing information on household characteristics, livelihood strategies, land use history, and involvement with the banana plantations. Twelve focus group discussions and twelve semi-structured interviews with villagers were subsequently used to explore these themes in greater depth. To examine the dynamics of the banana plantation expansion further, twenty-two semi-structured interviews were conducted 
with village authorities and land brokers, middlemen, banana investors, plantation managers, banana buyers, and banana workers in the area, as well as twenty-seven interviews with government officials from the five provincial and district departments involved in agricultural investments (The Agricultural and Forestry Department; the Department of Environment and Natural Resources; the Department of Planning and Investment; the Department of Trade and Industry; and the Department of Social Welfare and Labour). All interviews were conducted in Lao, Lue, or Chinese language with the assistance of a translator and were digitally recorded. The interviews were subsequently transcribed and translated into English before being coded and analysed using QSR Nvivo software, as were field notes from participant observation. The household questionnaires were coded and analysed in MS Excel. We use the unofficial village name preferred by the villagers themselves, whereas the names of companies and informants have been changed to ensure anonymity.

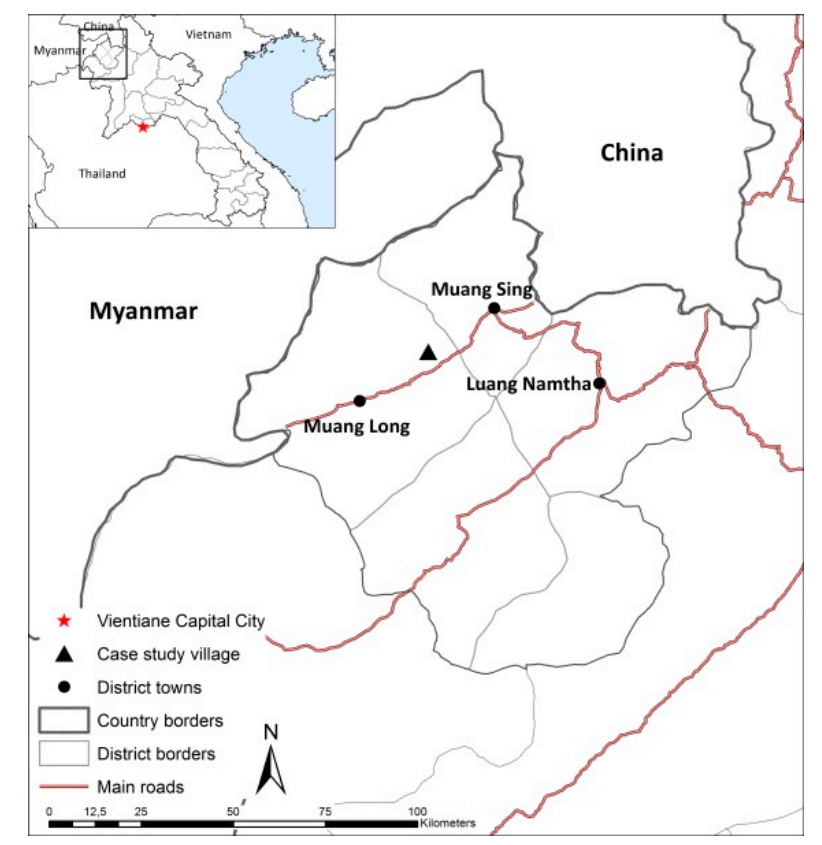

Figure 1. Map of the study area with indication of the case village location in Muang Long District, Luang Namtha Province.

\section{Setting the Scene: The Case of Banana Expansion in Luang Namtha Province}

\subsection{Land Use and Agricultural Change in the Lao Borderlands}

The expansion of banana cultivation in Luang Namtha Province represents the latest boom crop in an area that has long been influenced by 'external' actors and 'distal drivers' of land use change. The geopolitical struggles during the First and Second Indochina Wars (1945-1954 and 1959-1975) greatly influenced access to and the use of land, and since the establishment of the Lao People's Democratic Republic in 1975, the country's northern borderlands have been strongly influenced by state territorialisation efforts aimed at controlling land use and land users through various land and population management schemes [84-86]. Economic and political reforms initiated by the Government of Laos' (GoL) in the 1980s and the large push for "turning land into capital" since the early 2000s [87-89], combined with the growing economic strength of neighbouring countries, have resulted in a formal integration of the economy in the wider region, bringing with it a substantial increase in transnational investments in land and agricultural production [90-93].

In addition to formal foreign investments, the agricultural and economic developments in Luang Namtha are heavily influenced by more 'informal' economic interactions between borderland people [94,95]. A general expansion of cash-crop production in the province over the past decade is to 
a large extent driven by borderland Chinese people with ethnic relations in Luang Namtha Province. Rubber-the dominant cash-crop in the province-was, for example, introduced in the early-1990s by smallholders with cross-border family relations $[94,96]$. When the first commercial banana investments began to surface in Luang Namtha Province around 2007-2008, they were likewise primarily promoted by small Chinese companies and investors with social ties in the area, who leased land from Lao farmers (see also [97-99]). The banana investors mainly target the lowland areas along rivers and roads, where a widespread transformation of rice paddies to mono-cropped banana plantations has taken place. No province-wide inventory of the banana investments was available, but statistics from the Food and Agriculture Organization of the United Nations show that the area of banana harvested per year has increased continuously at the national level since the mid-1990s, and especially since 2010 [100]. In Muang Long District, where the main part of our empirical work took place, an official record from November 2014 included thirteen legally registered banana investment companies leasing a total of 820.75 hectares of land. However, this is likely a conservative estimate, since new plantations were being established at the end of 2014 and in 2015 [99].

\subsection{Ban Sirimoon}

The village of Ban Sirimoon, a small rural community in Muang Long District (323 people in 66 households in August 2014), is mainly inhabited by the Samtao ethnic minority. Mirroring the turbulent history of the country, the community moved and fled on several occasions during the Second Indochina War, before settling in today's Muang Long District in around 1973. A series of internal disputes and severe health problems led the villagers to move again and finally settle in their current location between 1989 and 1993. At that time, a small group of nine or ten families moved back to the community's original settlement at the Mekong River and only re-joined the rest of the village in 2003 as a result of the GoL's resettlement and village consolidation policy [86,101]. Presently, the village is located on the main district road connecting the Muang Long town in the west with Muang Sing District to the east—-the border-town and main trading hub of the area (See Figure 1). The village area consists of a narrow strip of lowland fields around the Nam Ma River and the hilly uplands on both sides of the valley. In 2001, the village was subject to the GoL's Land Use Planning and Land Allocation (LUPLA) programme [84,102-104], where village boundaries were defined and land (re)distributed between neighbouring communities, and the number of officially permitted upland fields per household was limited to three for upland farmers and two for households with paddy land. The succession of settlements and the outcomes of the LUPLA process influence the distribution of land among households in the village today. First-comers in 1989 could clear the best lowland areas for establishing paddy rice fields, while the people resettled by the government in 2003 were left to depend on more marginal upland areas given by relatives or allocated by the village authority. The LUPLA, in turn, entailed a redistribution of land between neighbouring villages and through this process, some households lost their fields and had to establish new fields on land further away. Currently, depending on this distribution of land and the availability of labour in the household, the villagers cultivate lowland rice (na), upland rice (hai), or a combination. Aside from small plots of maize and cassava, the commercial agricultural production in the village is concentrated on sugarcane in the uplands and pumpkin in the lowlands during the dry season (November-March), all cultivated on contracts with Chinese traders. In addition, some households have rubber gardens, although no households were tapping for latex yet, due to very low rubber prices (see [105]). In 2010, the village was incorporated into the banana boom, when two Chinese banana companies-the LFA Company and the XG Company-leased 35 and 46 hectares of land in the village on six year contracts.

\section{Results: A Telecoupled Banana Land System}

Drawing on an epistemological systems approach, we define the agricultural system around the banana production as our 'system of interest' $[20,70]$ in the telecoupling analysis. With the broad objective of understanding how and why the land use change to banana took place and with what 
outcomes, our geographical starting point for the analysis was the land use change from mainly rice to banana in Ban Sirimoon. While an ontological place-based approach to the system allows for setting boundaries a priori, a heuristic epistemological approach leaves the question of boundaries open to empirical analysis. Therefore, by 'following' the information provided by our informants, we move analytically from the banana fields to the wider village area, the district, the banana production network, and eventually the provincial regulatory context, in order to capture the actors, causes, and effects that are not necessarily spatially bound to the local area, but are nonetheless central for the conversion to banana in and around the village. In the following, we sketch out the main elements and interactions making up this banana land system.

\subsection{The Land Use Change}

The two banana investment companies arriving in Ban Sirimoon in late 2010 and implementing the plantations in 2011 targeted a particular lowland area adjacent to the village's housing area. Until that time, this area mainly consisted of paddy rice fields and a few plots of sugarcane, vegetable gardens, and young fallows. Nineteen households agreed to the leasing arrangements proposed by the two companies (thirteen and six households, respectively), and among the sixteen who participated in the questionnaire survey, an average of 0.93 hectares of land per household (ranging from 0.2 to 1.44 hectares) was leased out to grow bananas. Most of these households were first-comers or descendants of first-comers in the area, who had access to clear lowland patches of land. The rest of the land making up the two plantations was leased from people in neighbouring villages.

Establishing banana plantations entails a complete clearing and tilling of the land, resulting in a destruction of traditional irrigation channels, as well as plot boundaries marking the separation of individual fields. In the XG plantation, a small net of gravel stone roads had been established, and both companies installed irrigation systems. Moreover, banana cultivation requires the use of chemical fertilisers, pesticides, herbicides, fungicides, and growth-enhancers sprayed heavily in the first growing months and more moderately during the ripening of the fruit. At the time of our fieldwork, the banana crop was in its fourth growing season (which is generally between ten and fourteen months), and plantation managers explained that the seedlings are normally productive for three to five seasons, after which they need to be replaced. Accordingly, short-term contracts were preferred by the investors, and several of them emphasised how this arrangement provided them with the flexibility needed to move to new areas if the land were to be degraded or the soil infected with Panama Disease, a soil-pathogenic fungus causing irreversible infection in banana roots $[97,99,106]$. The push for banana into Laos was explained by investors in relation to, among other things, a growing demand for Lao bananas due to degraded banana land systems in the tropical regions of China and to typhoon-risk in the same regions, as well as in banana producing regions in the Philippines (see also $[107,108])$.

\subsection{Actors and Access to Land in the Banana Production Network}

To get access to the land, both companies relied on personal acquisition strategies. They hired local middlemen to identify suitable land and facilitate the contract negotiations. The LFA Company-a joint venture of five Chinese investors of mixed ethnicity—relied on the personal relationships of its Tai Lue Chinese partner to employ a well-connected Lue village headman as their main middleman. The XG Company, owned by a Han Chinese investor with more than twenty years of business experience in the area, likewise hired a well-connected local businessman to conduct his land survey. In turn, both middlemen, who also lived in the area, used their local knowledge and social network to engage two of their old acquaintances as land brokers in Ban Sirimoon. The land brokers acted as 'first-movers' for accepting the deals and used their position in the village to convince other households to join. This instated an atmosphere of peer-pressure, which several interviewees explained made them feel obliged to accept the proposals and "to follow the decision of the others"- despite concern for their own rice security and for the long-term effects on their land. Investors and middlemen further increased 
pressure on people reluctant to join by highlighting the threats that not leasing their land would pose, including the lack of adequate access to their fields and to irrigation water for paddy rice production, as well as the side-effects of chemicals on adjacent crops. The targeted acquisition strategy meant that the rest of the village's households were not involved in the decision-making process. In general, villagers who were not part of the leasing schemes shrugged when asked about the decision of the others, with comments such as "it is their land, they can decide what they want to do."

The XG Company initially operated on behalf of another Chinese investor, who remained absent from the negotiation process and eventually sold the plantation after a year to another Chinese investor. However, the company remained an intermediary for the new investor in dealings with the villagers, as well as the district authorities. In 2015, the LFA Company likewise sold their plantation. Several other banana companies operating in the Muang Long district adopted a similar role as intermediaries and thus made it possible for investors with little knowledge of Laos to get access to their social networks among villagers and the local government. While most of the interviewed investors explained that their initial investment capital comes from personal savings and/or loans from relatives and relations "back home" in China, a subset of the plantations are set up with financial backing from wealthy Chinese investors and companies.

For managing the banana cultivation, the LFA Company hired an experienced Chinese plantation manager, whereas the XG Company employed a Tai Lue Chinese farmer married to a woman in Ban Sirimoon and some experienced Chinese plantation workers to carry out the cultivation. The practice of bringing in technical staff from China to manage the cultivation was common in plantations throughout the district. In addition, contract workers are employed on a seasonal basis to take care of a specified number of banana trees. Except for two younger households from Ban Sirimoon, one working for four years for the XG and the other working for a year for the LFA in 2014, the contracted workers in the two plantations are predominantly migrants from China brought in by the Chinese investors and from other provinces in Laos. In addition, casual wage-workers are hired on a daily basis in peak cultivation periods for planting, weeding, and harvesting, partly from Ban Sirimoon and partly from other villages in the area.

All the bananas are exported to China as fresh-fruit produce, linking plantation development to the increasing demand in major urban systems in China (see [109]). Some investors noted that they had experienced an increasing demand for bananas from Laos in previous years, due to Chinese import restrictions on bananas from the Philippines, related to the political conflicts around territorial rights in the South Chinese Sea [110,111]. This Chinese-Philippine banana trade dispute, it was noted, had further incentivised the expansion of cultivation into Laos, although the Chinese authorities lifted these import restrictions again in October 2016 following an increasing rapprochement between the two countries and the downplaying of the conflict by the Philippine President Duterte [110,112-114]. The buyers encountered during fieldwork were shipping the bananas as far as Beijing, Shanghai, and several northern regions bordering Russia. The bananas from the XG plantation in Ban Sirimoon in 2015 were, for example, sold to buyers from Tianjin and Sichuan provinces. A few of the interviewed investors noted that they used personal contacts in the fruit-trading industry in China to contact buyers directly, but most explained that they relied on the assistance of intermediary trading agencies in China to facilitate the negotiations with potential buyers. Despite mandatory export permits and strict production and export taxing regulations, district officials noted that many investors avoided the official procedures by paying off the border authorities. In turn, investors complained that bureaucracy and the non-transparent export process, including continuously increasing border fees and taxes, were becoming an increasing hassle. In particular, it was noted that the provincial authorities in Luang Namtha Province had granted all export rights of banana, as well as other fruit crops, to a single export company, which had substantially increased the border fees. 


\subsection{Human and Environmental Effects of the Banana Plantations}

The reasons given by people in Ban Sirimoon for joining the banana schemes were primarily economic. Both companies paid leasing fees of 10 million Laotian Kip (LAK) per hectare per year ( 1 USD $\approx 8078$ LAK in 2014 (The Bureau of Fiscal Services, US department of Treasury, exchange rate 31 December 2014; https://www.fiscal.treasury.gov/fsreports/rpt/treasRptRateExch/itin-12-31-2014. pdf), and the involved households earned 2-17 million LAK annually, depending on the size of their land plot (on average, around 9 million LAK). The fields had suffered from a periodic lack of water and the production of surplus rice was thus limited, making the leasing fees substantially higher than the possible income from the sale rice. Stories of successful engagement with banana and cash-crops reaching the villagers from rural areas in southern China, as well as information about other villages in Luang Namtha engaging with banana investors at the time of the contract negotiations, were also noted to influence some villagers' incentives to engage in similar ventures (see also $[95,115])$. Some middlemen and investors stated that similar stories were used to incentivise Lao farmers to accept the deals. In thirty-one of the surveyed households, one or more household members had occasionally worked for the banana plantations in 2014 for wages ranging from 50,000 LAK to 200,000 LAK per day, depending on the 'heaviness' of the tasks. The reported average annual income from such work was 1.5 million LAK, ranging from 250,000 to 10 million.

The income from banana leasing fees and wage work is comparable to other agricultural and non-agricultural income sources in the village, mainly sugarcane, pumpkin, handicraft, and non-agricultural wage work such as construction work. For sugarcane, for example, the income ranged from 1.3 to 32.5 million LAK for the harvest in 2014 (average among 25 households, 11.4 million LAK, the 32.5 million was earned in the household with a large plot of sugarcane, 1.5 hectares, compared to the average plot of 0.95 hectares). Sugarcane is, however, labour intensive and considered very hard work, especially among older villagers. In contrast, leasing land to banana plantations was often referred to as "earning money without working", thus freeing up time for other activities. Overall, the income from cash-crop production has allowed the villagers to invest in house construction, small business ventures, or new consumer goods, especially motorbikes. Such investments are important for status in the village, as indicated in repeated statements by villagers referring to the importance of "improving" themselves and "following the society's development." The villagers also stressed an increase in the general need for cash to pay for costs of electricity, new food products, medicine, schooling, and taxes.

In addition to these economic implications for households, the villagers reported a number of social and environmental effects of the plantations. The complete transformation of the paddy rice field structures was a concern for the involved households, who worried that they would not be able to properly "turn back the land" to other agricultural uses after the end of the contracts. People also expressed fear of the potential for future land conflicts, since the traditional plot borders had been destroyed and only some households had managed to invest in stone markers to indicate their field boundaries. This, along with concerns for the cost of re-establishing their fields, led many banana households to express an expectation that they would accept an extension of the contracts if offered one by the investors and if the leasing fees were raised to match the rising land prices in the area.

Independent of their involvement in the plantations, people voiced concerns about food security in relation to the wide-ranging conversion of rice paddies to banana throughout Muang Long and neighbouring Muang Sing districts. The villagers were increasingly relying on purchased rice-not only due to the banana plantations, but also to the general conversion of both upland and lowland rice fields to cash-crops. Thirty-one of the forty-eight surveyed households no longer produced enough rice to feed themselves for the entire year, and among the banana leasing households, only four of the sixteen households produced enough. A general concern over rising rice prices in the district was therefore noted by several people. Moreover, many villagers worried about a number of indirect impacts related to the excessive use of chemicals in the plantations. Fear of the effects on water quality and the environment more generally was rising, as some farmers with plots adjacent to the 
plantations had experienced damage to their crops. Many people also reported that breathing and sleeping problems often followed the spraying in the plantations, and insecurities about the long-term health impacts were indicated, especially with regards to the youngest school children since the banana plantations surrounds the village primary school. A former village headman of Ban Sirimoon noted during an interview that the villagers had raised the environmental and health issues with the district environmental authorities, who had recently come to inspect the plantations. Despite warning the plantation manager to change practices within two weeks, the environmental office staff had never returned for a second inspection-according to the former village headman, because the investor had paid them off. Although the district officials interviewed acknowledged the issues with chemical pollution, they stressed their lack of budget and trained staff as reasons for their problems to enforce the regulations.

\subsection{Governance Structures and Attempted Regulation of the Banana Production}

As for any other type of foreign investment in land and agricultural production in Laos [92,116], the banana investments are subject to the GoL's land use regulations. Investors are officially required to obtain investment permits after identifying the desired land and before establishing the plantations. Investment proposals should be evaluated based on an inspection of the targeted area, an agricultural feasibility study, a mapping of plot boundaries, an environmental impact assessment and a general consideration for the viability and desirability of the proposed investment. In reality, however, government interviewees noted that this process hardly ever takes place before the plantations have been implemented and emphasised the difficulties in regulating and controlling the spread of banana. The main explanation given was that the investors' informal land acquisition strategies at a village level made it difficult for the district authorities to intervene before the plantations were already implemented. In some cases, investors had paid deposits to the landholders up front, and most only applied for permission after the land had already been tilled. Moreover, the widespread use of intermediaries, as well as the sales and resales of plantations between investors, were highlighted as factors making it difficult to oversee and control plantation development. Stories of corruption and patron-client relationships between high-ranking district officials and several investors were also reported to play a role in the lack of formal regulation.

Generally, all interviewed government officials expressed concern for the conversion of paddy rice fields to banana. They highlighted that Luang Namtha Province is officially appointed a strategic rice producing province in the national food security plan, and the banana conversion hence threatened this objective, as well as the rice security of the farmers involved. As a result, the provincial and central governments made several attempts to halt the banana expansion. A province-wide moratorium on banana plantations on paddy fields was issued by the Provincial Governor in 2011, and in 2014, a Prime Ministerial Decree placed a national ban on the conversion of paddy fields to banana plantations. However, in addition to problems with corruption, several informants noted that both the farmers' and the investors' economic incentives to lease the land outweighed any concern for the potential retribution of establishing new plantations, and plantations continued to be established throughout 2014 and 2015. In the fall of 2016, the Lao media reported yet another moratorium for all banana cultivation in the northern provinces $[117,118]$.

In sum, the findings presented here describe the central components making up a telecoupled banana land system. This system consists of the fields of banana, as the place-based component of the system, and the networks of actors and governance institutions influencing the land use change, as the processual component of the system. Through these networks, capital investment, bananas, environmental influences, and economic incentives, among others, flow and create telecouplings that constitute the banana system as, for example, a sending system for the produce linking it to urban consumer markets in China, a receiving system for environmental pressure linking it to degrading banana land systems in China, and a spill-over system in relation to the increased demand following the Chinese-Philippine banana trade dispute (Section 5.2) (see also [33]). 


\section{Discussion: Implications and Solutions for System Boundary Choices}

As LSS takes steps towards bridging place-based and processual analysis, the telecoupling framework has emerged as an analytical approach that has proven useful for studying land use and human-environment system changes in an increasingly globalised world (e.g., $[17,40,41,119,120])$. The telecoupling perspective moves the study of land use change forward by highlighting networked and relational aspects of such changes, while maintaining the usefulness of analysing human-environment interactions as complex place-based systems [12,42]. Integrating these two perspectives, however, remains a challenge, especially with regards to the question of system boundaries and how to define systems as 'separate' and 'distant' rather than as one larger, integrated whole.

So far, a 'classical' approach to coupled human-environment systems, and especially land systems, as spatially discrete entities separated by geographical or institutional distance, has facilitated a number of solid studies of telecoupling and globalized land use change [25,26]. However, while such an approach allows for setting system boundaries a priori, it also risks black-boxing the complexity of social-ecological processes and in particular the networked interactions cutting across such 'entities'. In this paper, we drew on the growing acknowledgement within LSS for embracing different disciplinary perspectives on, for example, social space, place, and scale $[21,22,29,53-55,121]$ to highlight the need for rethinking the analytical category of 'the system' within telecoupling research. By engaging with the systems thinking literature and in particular with what has been termed a 'soft' or 'epistemological' systems approach, telecoupling research can deal with 'the system' as a networked and fluid category that is not necessarily confined to a given spatial or institutional place. Such process-oriented, and to some extent social constructivist, research approaches present the means to tackle the challenge of setting system boundaries in a world defined by interconnectivity and flows of resources, ideas, and people, because it implies that systems are intellectual constructs rather than predefined entities given by any 'natural' extent, resolution, or geographical and institutional distance [20,71]. This allows for the drawing of system boundaries, or the definition of a 'system of interest', that escapes arbitrary definitions, but captures empirical conditions regardless of these being place-based or networked across physical and social space.

The epistemological systems approach has a number of implications for how we analysed the recent banana boom in northern Laos as a telecoupled land system. First, it allowed us to understand how 'the system of interest' extended to actors not actually living in the village area studied. Indeed, without embedding these 'external' actors in our 'banana land system', we would not have captured the extent to which and how the presence of a network of agricultural investors with knowledge and social ties to Laos, as well as connections and social networks in China, shaped the banana expansion. A place-based and an institutional land system approach defining, for example, the village (or Northern Laos) as one system and China as another, would indeed have complicated the task of capturing the role of these investors, as well as ignored the fact that this area is a 'porous' border region where people have long had economic and social engagements with each other, despite being separated physically and institutionally residing in two different countries [94-96,122]. By analytically constructing the banana system as we did, it was possible to capture the 'functional' importance to this system of the social space created in the interactions between the investors, the local middlemen, and the Lao farmers.

Second, internalising these actors in the banana system facilitated an understanding of how the land use change is actually telecoupled. By exploring how our 'banana land system' was constituted by different flows linking this land use change to processes elsewhere, our analysis showed that the investors play a key role as both 'receivers' of the market signal to make banana plantations from outside our system, for example, from Chinese government policies, and 'senders' of the material flow of the fruit, for example, to urban markets in China. Similarly, they partly conveyed the information about economic prosperity among banana farmers elsewhere, influencing the participating villagers' desire for similar economic development and thus facilitating the creation of informationand 'discursive' telecoupling. As such, we were able to better understand a very important, and so 
far unexplored, aspect of telecoupled land systems, namely how various 'flows' were 'transmitted' through existing networks of actors, as well as which of these actors-here, predominantly the Chinese investors-had the power to influence this transmission. Furthermore, integrating these foreign land investors into our system of interest enabled our understanding of how the Chinese investors acquired access to land and how the success of these acquisitions are captured analytically, exactly by not viewing the investors as 'external agents'. Indeed, the 'boundary' to the Chinese companies was effectively effaced in this 'banana land system' because they were always represented by and relying upon local intermediaries, middlemen, and village land brokers to gain access to land.

That the formal institutional and spatial separations of these companies and the local landholders were thus dissolved also partly illustrates why the GoL's efforts to control the plantation expansions are currently failing, since the companies are within 'the system' and as such can circumvent the government's efforts to control them. Here, again, the Chinese investors' position in the system enabled them to assert power and influence over the land use change in a manner that cut across established institutional 'scales'. A further and more general point here is that our case illustrates the misfit between the territorial governance arrangements and the functioning of this land system, something increasingly discussed within LSS in relation to the need for developing better synergies between territorial land management structures and flow-based interventions in agricultural production networks [123-127]. However, where these discussions have so far generally drawn on points from the global production network and value chains literature, the system thinking approach advocated in this paper adds a more social constructivist perspective to these discussions.

Thus, a third point is that adopting an epistemological system approach enabled us to interrogate what and who is excluded from the analysis, and with what implications. By constituting the banana land system as the actors, causes, and effects directly involved in the conversion from rice to banana, the part of the landscape and village community not directly related to the land use change were externalised. Doing this, our analysis demonstrated that from a place-based perspective, the village is not 'telecoupled' to the same extent. Indeed, the investors' targeted land acquisition strategies played into a historically determined land-ownership pattern, where only households with lowland fields were targeted for participation in the leasing scheme. This introduced an economic and social distinction between participating and non-participating households in the village related to rental incomes and wage labour, as well as exclusion from decision-making processes. However, the part of the village not directly related to the 'banana land system' was nonetheless still affected by it. This point is most clearly present when considering the longer-term effects on the entire village of soil degradation and environmental pollution, health issues related to heavy chemical inputs, and rising rice prices and increasing pressure on the upland rice production that have to compensate somewhat for the reduction in lowland rice production due to the plantations. Demarcating our system boundaries the way we did thus also illustrates that spill-over effects can be found in the same geographical location. In light of continued calls for more attention to spill-over effects and spill-over systems within the telecoupling literature (e.g., $[11,128,129])$, the socioeconomic distance created between households in the village, the pollution issues, and the effects on the upland land systems illustrate that 'systems' need not be located far away in terms of geographical distance. Creating a better understanding of such differentiated outcomes of telecouplings thus requires us to move beyond the notion of distal flows and processes acting in coherent and existing human-environment systems, and instead focus our attention on describing and unpacking their constitution. By showing how direct and indirect effects of telecouplings are found not only over geographical and functional distance, but by social distance as well [21,29], the case presented here illustrates the importance of such 'unpacking'. Similar points have been raised by other authors concerned with the distributed effects and agency among farmers facing distal demands for their land resources $[13,15]$.

Finally, this discussion clearly highlights how a formulation of a 'system of interest' is embedded with analytical choices: we could have defined the system of interest in another way. Defining a system and bounding it off from its 'environment' will therefore always be influenced by the 
particular interest and perspective of the researcher(s); it is never naturally given [70]. In light of recent advancements in the literature on human-environment relations that emphasise the existence of looping effects between analytical choices, problem framing, and recommended interventions $[4,81]$, explicit consideration is needed with regards to how our choice of system boundaries-be they administrative, spatial geographical, or others-influence our results. This is particularly crucial for the increasing efforts going into the quantification, modelling, and potentially scenario-building of telecoupled systems $[11,130,131]$, but also, as illustrated by our analysis in this paper, for the case study research of telecoupling of local land use change. Since spatial scale categories such as local, regional or global, and national or subnational administrative borders are likely to remain relevant as system boundaries for some studies (especially given issues related to data availability for spatial and statistical modelling), epistemological systems thinking reminds us that such boundaries are neither 'naturally given' nor necessarily the most suitable ones. This forces us to critically reflect on the trade-offs implied by confining analysis to these types of system boundaries $[54,67,132]$. As LSS and the wider field of human-environment systems research continue to engage in questions with relevance for the broader policy and solution-oriented debates on environmental and social sustainability $[11,12,20,74]$, a critical examination of such trade-offs will be crucial.

\section{Conclusions}

In this paper, we have engaged with the analytical challenge of setting system boundaries in telecoupling research of land use change. The telecoupling framework has been proposed to address the cross-scalar flows, networks, and interactions over distance that increasingly influence land use and other changes in coupled human-environment systems. The strength of the telecoupling framework is that it deals with global connectivity in a systemic and systematic manner, while opening up to relational and processual approaches. For an empirical analysis of telecoupled systems, however, a question remains regarding how to understand systems as separate and distant, as opposed to one larger integrated whole. Here, we have argued that engaging with insights from the systems thinking literature that distinguish between 'hard' and 'soft' or 'ontological' and 'epistemological' systems approaches holds potential solutions for this challenge. In stressing how all formulations of systems are analytically constructed from the objectives, interests, and position of the researcher, this literature provide the means to move from a 'conventional' understanding of land systems as bounded 'ontological entities' to flexible epistemological constructs. This enables the analysis of particular land use changes or other environmental shifts as coupled systems, regardless of the 'location' of the human and natural components of the system.

By exemplifying these perspectives, we analysed the recent banana boom in northern Laos as a telecoupled banana land system. Starting with the banana plantations in a rural village and its surroundings, we identified the actors, their relations and networks, and the institutions that were central to the land use change and thus central to the 'creation' of the banana land system. The banana land system was therefore constructed and understood as the lowland fields, the villagers leasing out the land, the stakeholders in the cross-border banana production network, and the governance institutions aimed at regulating the land use change. Moreover, explicitly reflecting upon what and who we included in the banana land system allowed us to 'unpack' the differentiated involvement and effects, both environmental and socio-economic, in the village. The analysis illustrated that from a place-based perspective, the entire village is not 'telecoupled' to the same extent. These points raise important questions about the constitution and framing of systems defined as sending, receiving, and spill-over systems in telecoupling analysis, and cautions against leaving them 'black-boxed'. In recognising that all systems are epistemological constructs, explicit attention to the trade-offs and implications of systems definitions becomes more evident. We believe that such an awareness of scale and boundary choices is essential for further developing the agenda on telecoupling. 
Acknowledgments: This study is funded by the German Excellence Initiative. The fieldwork was carried out as part of the EU-funded project "Impacts of Reducing Emissions from Deforestation and Forest Degradation and Enhancing Carbon Stocks (I-REDD+)" (EU FP7-ENV-2010, Project No. 265286) in collaboration with and with extensive support from the Faculty of Forestry, the National University of Laos. Thanks are extended to the Provincial Authorities in Luang Namtha Province and the District Authorities in Muang Long and Muang Sing districts for their support throughout the fieldwork. Thanks to the villagers in the study site for their great hospitality, patience, and contributions to the study, to Mr. Soukkaseum for invaluable research assistance and translations, and to Dr. Kelly Hopping, Janine Hauer, and Ruzana Liburkina for their useful comments. We also thank two anonymous reviewers for their comments on the first draft. Any remaining shortcomings or mistakes are our own.

Author Contributions: Cecilie Friis conceived the idea, conducted the fieldwork and case study, and drafted and finalized the manuscript. Both authors contributed to the analysis and discussion, writing parts of the paper, and commenting on draft versions.

Conflicts of Interest: The authors declare no conflict of interest.

\section{References}

1. Müller, D.; Munroe, D.K. Current and future challenges in land-use science. J. Land Use Sci. 2014, 9, $133-142$. [CrossRef]

2. Turner, B.L.; Lambin, E.F.; Reenberg, A. The emergence of land change science for global environmental change and sustainability. Proc. Natl. Acad. Sci. USA 2007, 104, 20666-20671. [CrossRef] [PubMed]

3. Lambin, E.F.; Meyfroidt, P. Global land use change, economic globalization, and the looming land scarcity. Proc. Natl. Acad. Sci. USA 2011, 108, 3465-3472. [CrossRef] [PubMed]

4. Niewöhner, J.; Bruns, A.; Hostert, P.; Krueger, T.; Nielsen, J.Ø.; Haberl, H.; Lauk, C.; Lutz, J.; Müller, D. Land Use Competition: Ecological, Economic and Social Perspectives; Springer: Cham, Switzerland, 2016; Volume 6, 377p.

5. Seto, K.C.; Reenberg, A. Rethinking Global Land Use in an Urban Era; The MIT Press: Cambridge, MA, USA, 2014.

6. Liu, J.; Hull, V.; Batistella, M.; DeFries, R.; Dietz, T.; Fu, F.; Hertel, T.W.; Izaurralde, R.C.; Lambin, E.F.; Li, S.; et al. Framing sustainability in a telecoupled world. Ecol. Soc. 2013, 18, 26. [CrossRef]

7. Eakin, H.; DeFries, R.; Kerr, S.; Lambin, E.F.; Liu, J.; Marcotullio, P.J.; Messerli, P.; Reenberg, A.; Rueda, X.; Swaffield, S.R.; et al. Significance of telecoupling for exploration of land-use change. In Rethinking Global Land Use in an Urban Era; Seto, K.C., Reenberg, A., Eds.; The MIT Press: Cambridge, MA, USA, 2014; pp. 141-161.

8. Challies, E.; Newig, J.; Lenschow, A. What role for social-ecological systems research in governing global teleconnections? Glob. Environ. Chang. 2014, 27, 32-40. [CrossRef]

9. Lenschow, A.; Newig, J.; Challies, E. Globalization's limits to the environmental state? Integrating telecoupling into global environmental governance. Environ. Politics 2016, 25, 136-159. [CrossRef]

10. Erb, K.-H.; Krausmann, F.; Gaube, V.; Gingrich, S.; Bondeau, A.; Fischer-Kowalski, M.; Haberl, H. Analyzing the global human appropriation of net primary production-Processes, trajectories, implications. An introduction. Ecol. Econ. 2009, 69, 250-259. [CrossRef]

11. Liu, J.; Mooney, H.; Hull, V.; Davis, S.J.; Gaskell, J.; Hertel, T.; Lubchenco, J.; Seto, K.C.; Gleick, P.; Kremen, C.; et al. Sustainability. Systems integration for global sustainability. Science 2015, 347, 1258832. [CrossRef] [PubMed]

12. Global Land Programme(GLP). Science Plan and Implementation Strategy 2016-2021. 2016. Available online: https://glp.earth/sites/default/files/uploads/glpscienceplan_25_10_16.pdf (accessed on 6 June 2017).

13. Vadjunec, J.; Radel, C.; Turner, B.L. Introduction: The continued importance of smallholders today. Land 2016, 5, 34. [CrossRef]

14. Verburg, P.H. Key Note Address Glp-Osm 2016; Beijing, China, 2016. (oral presentation).

15. Eakin, H.; Winkels, A.; Sendzimir, J. Nested vulnerability: Exploring cross-scale linkages and vulnerability teleconnections in mexican and vietnamese coffee systems. Environ. Sci. Policy 2009, 12, 398-412. [CrossRef]

16. Adger, W.N.; Eakin, H.; Winkels, A. Nested and teleconnected vulnerabilities to environmental change. Front. Ecol. Environ. 2009, 7, 150-157. [CrossRef]

17. Baird, I.G.; Fox, J. How land concessions affect places elsewhere: Telecoupling, political ecology, and largescale plantations in southern laos and northeastern cambodia. Land 2015, 4, 436-453. [CrossRef]

18. Seaquist, J.W.; Johansson, E.L.; Kimberly, A.N. Architecture of the global land acquisition system: Applying the tools of network science to identify key vulnerabilities. Environ. Res. Lett. 2014, 9, 114006. [CrossRef] 
19. Chignell, S.M.; Laituri, M.J. Telecoupling, urbanization, and the unintended consequences of water development aid in ethiopia. Geol. Soc. Am. Spec. Pap. 2016, 520, 125-135.

20. Abson, D.J.; Fischer, J.; Leventon, J.; Newig, J.; Schomerus, T.; Vilsmaier, U.; von Wehrden, H.; Abernethy, P.; Ives, C.D.; Jager, N.W.; et al. Leverage points for sustainability transformation. AMBIO 2017, 46, 30-39. [CrossRef] [PubMed]

21. Friis, C.; Nielsen, J.Ø.; Otero, I.; Haberl, H.; Niewöhner, J.; Hostert, P. From teleconnection to telecoupling: Taking stock of an emerging framework in land system science. J. Land Use Sci. 2016, 11, 131-153. [CrossRef]

22. Munroe, D.K.; McSweeney, K.; Olson, J.L.; Mansfield, B. Using economic geography to reinvigorate land-change science. Geoforum 2014, 52, 12-21. [CrossRef]

23. Liu, J.; Hull, V.; Luo, J.; Yang, W.; Liu, W.; Viña, A.; Vogt, C.; Xu, Z.; Yang, H.; Zhang, J.; et al. Multiple telecouplings and their complex interrelationships. Ecol. Soc. 2015, 20, 44. [CrossRef]

24. Liu, J. Forest sustainability in china and implications for a telecoupled world. Asia Pac. Policy Stud. 2014, 1, 230-250. [CrossRef]

25. Schierhorn, F.; Meyfroidt, P.; Kastner, T.; Kuemmerle, T.; Prishchepov, A.V.; Müller, D. The dynamics of beef trade between brazil and russia and their environmental implications. Glob. Food Secur. 2016, 11, 84-92. [CrossRef]

26. Gasparri, N.I.; Kuemmerle, T.; Meyfroidt, P.; le Polain de Waroux, Y.; Kreft, H. The emerging soybean production frontier in Southern Africa: Conservation challenges and the role of south-south telecouplings. Conserv. Lett. 2015, 9, 21-31. [CrossRef]

27. Deines, J.M.; Liu, X.; Liu, J. Telecoupling in urban water systems: An examination of Beijing's imported water supply. Water Int. 2015, 41, 251-270. [CrossRef]

28. Cumming, G.S.; Cumming, D.H.; Redman, C.L. Scale mismatches in social-ecological systems: Causes, consequences, and solutions. Ecol. Soc. 2006, 11, 14. [CrossRef]

29. Niewöhner, J.; Nielsen, J.Ø.; Gasparri, I.; Gou, Y.; Hauge, M.; Joshi, N.; Schaffartzik, A.; Sejersen, F.; Seto, K.C.; Shughrue, C. Conceptualizing distal drivers in land use competition. In Land Use Competition; Springer: Cham, Switzerland, 2016; Volume 6, pp. 21-40.

30. Ison, R. Systems Practice: How to Act in a Climate Change World; Springer: Berlin, Germany, 2010.

31. Midgley, G. Science as systemic intervention: Some implications of systems thinking and complexity for the philosophy of science. Syst. Pract. Action Res. 2003, 16, 77-97. [CrossRef]

32. Jones, S. Social constructionism and the environment: Through the quagmire. Glob. Environ. Chang. 2002, 12, 247-251. [CrossRef]

33. Luhmann, N. Ecological Communication; University of Chicago Press: Chicago, IL, USA, 1989.

34. Parsons, T. Social System; Routledge: Oxford, UK, 2013.

35. Erb, K.-H.; Krausmann, F.; Lucht, W.; Haberl, H. Embodied hanpp: Mapping the spatial disconnect between global biomass production and consumption. Ecol. Econ. 2009, 69, 328-334. [CrossRef]

36. Weinzettel, J.; Hertwich, E.G.; Peters, G.P.; Steen-Olsen, K.; Galli, A. Affluence drives the global displacement of land use. Glob. Environ. Chang. 2013, 23, 433-438. [CrossRef]

37. Schaffartzik, A.; Haberl, H.; Kastner, T.; Wiedenhofer, D.; Eisenmenger, N.; Erb, K.-H. Trading land: A review of approaches to accounting for upstream land requirements of traded products. J. Ind. Ecol. 2015, 19, 703-714. [CrossRef] [PubMed]

38. Reenberg, A.; Langanke, T.; Kristensen, S.B.P.; Colding, T.S. Globalisation of agricultural landscapes a land systems approach. In Globalisation and Agricultural Landscapes Change Patterns and Policy Trends in Developed Countries; Primdahl, J., Swaffield, S., Eds.; Cambridge University Press: Cambridge, UK, 2010; pp. 31-56.

39. Seto, K.C.; Reenberg, A.; Boone, C.G.; Fragkias, M.; Haase, D.; Langanke, T.; Marcotullio, P.; Munroe, D.K.; Olah, B.; Simon, D. Urban land teleconnections and sustainability. Proc. Natl. Acad. Sci. USA 2012, 109, 7687-7692. [CrossRef] [PubMed]

40. Butsic, V.; Kelly, M.; Moritz, M.A. Land use and wildfire: A review of local interactions and teleconnections. Land 2015, 4, 140-156. [CrossRef]

41. Gasparri, N.I.; le Polain de Waroux, Y. The coupling of south american soybean and cattle production frontiers: New challenges for conservation policy and land change science. Conserv. Lett. 2015, 8, 290-298. [CrossRef] 
42. Liu, J.; Hull, V.; Moran, E.; Nagendra, H.; Swaffield, S.; Turner, B.L. Applications of the telecoupling framework to land-change science. In Rethinking Global Land Use in and Urban Age; Seto, K.C., Reenberg, A., Eds.; The MIT Press: Cambridge, MA, USA, 2014.

43. Turner, B.L.; Kasperson, R.E.; Matson, P.A.; McCarthy, J.J.; Corell, R.W.; Christensen, L.; Eckley, N.; Kasperson, J.X.; Luers, A.; Martello, M.L.; et al. A framework for vulnerability analysis in sustainability science. Proc. Natl. Acad. Sci. USA 2003, 100, 8074-8079. [CrossRef] [PubMed]

44. Turner, B.L.; Matson, P.A.; McCarthy, J.J.; Corell, R.W.; Christensen, L.; Eckley, N.; Hovelsrud-Broda, G.K.; Kasperson, J.X.; Kasperson, R.E.; Luers, A.; et al. Illustrating the coupled human-environment system for vulnerability analysis: Three case studies. Proc. Natl. Acad. Sci. USA 2003, 100, 8080-8085. [CrossRef] [PubMed]

45. Young, O.R.; Lambin, E.F.; Alcock, F.; Haberl, H.; Karlsson, S.I.; McConnell, W.J.; Myint, T.; Pahl-Wostl, C.; Polsky, C.; Ramakrishnan, P.S.; et al. A portfolio approach to analyzing complex human-environment interactions: Institutions and land change. Ecol. Soc. 2006, 11, 31. [CrossRef]

46. Young, O.R.; Berkhout, F.; Gallopin, G.C.; Janssen, M.A.; Ostrom, E.; van der Leeuw, S. The globalization of socio-ecological systems: An agenda for scientific research. Glob. Environ. Chang. 2006, 16, 304-316. [CrossRef]

47. Haberl, H.; Fischer-Kowalski, M.; Krausmann, F.; Winiwarter, V. Social Ecology: Society-Nature Relations across Time and Space; Springer: Cham, Switzerland, 2016; Volume 5.

48. Folke, C.; Hahn, T.; Olsson, P.; Norberg, J. Adaptive governance of social-ecological systems. Annu. Rev. Environ. Res. 2005, 30, 441-473. [CrossRef]

49. Liu, J.; Dietz, T.; Carpenter, S.R.; Alberti, M.; Folke, C.; Moran, E.; Pell, A.N.; Deadman, P.; Kratz, T.; Lubchenco, J.; et al. Complexity of coupled human and natural systems. Science 2007, 317, 1513-1516. [CrossRef] [PubMed]

50. Veldkamp, A. Investigating land dynamics: Future research perspectives. J. Land Use Sci. 2009, 4, 5-14. [CrossRef]

51. Global Land Project (GLP). Science Plan and Implementation Strategy; IGBP Secretariat: Stockholm, Sweden, 2005.

52. Verburg, P.H.; Crossman, N.; Ellis, E.C.H.; Andreas; Hostert, P.; Mertz, O.; Nagendra, H.; Sikor, T.; Erb, K.-H.; Golubiewski, N.G.; et al. Land system science and sustainable development of the earth system: A global land project perspective. Anthropocene 2015, 12, 29-41. [CrossRef]

53. Massey, D. A global sense of place. Marx. Today 1991, 38, $24-29$.

54. Howitt, R. Scale as relation: Musical metaphors of geographical scale. Area 1998, 30, 49-58. [CrossRef]

55. Jessop, B.; Brenner, N.; Jones, M. Theorizing sociospatial relations. Environ. Plan. D Soc. Space 2008, 26, 389-401. [CrossRef]

56. Mansfield, B.; Munroe, D.K.; McSweeney, K. Does economic growth cause environmental recovery? Geographical explanations of forest regrowth. Geogr. Compass 2010, 4, 416-427. [CrossRef]

57. Cash, D.W.; Adger, W.N.; Berkes, F.; Garden, P.; Lebel, L.; Olsson, P.; Pritchard, L.; Young, O. Scale and cross-scale dynamics: Governance and information in a multilevel world. Ecol. Soc. 2006, 11, 8. [CrossRef]

58. Görg, C. Landscape governance: The "politics of scale" and the "natural" conditions of places. Geoforum 2007, 38, 954-966. [CrossRef]

59. Borgström, S.T.; Elmqvist, T.; Angelstam, P.; Alfsen-Norodom, C. Scale mismatches in management of urban landscapes. Ecol. Soc. 2006, 11, 16. [CrossRef]

60. Pelosi, C.; Goulard, M.; Balent, G. The spatial scale mismatch between ecological processes and agricultural management: Do difficulties come from underlying theoretical frameworks? Agric. Ecosyst. Environ. 2010, 139, 455-462. [CrossRef]

61. Taylor, M.J.; Moran-Taylor, M.J.; Ruiz, D.R. Land, ethnic, and gender change: Transnational migration and its effects on guatemalan lives and landscapes. Geoforum 2006, 37, 41-61. [CrossRef]

62. Borras, S.M.; Franco, J.C.; Gómez, S.; Kay, C.; Spoor, M. Land grabbing in latin america and the caribbean. J. Peasant Stud. 2012, 39, 845-872. [CrossRef]

63. Damon, A.L. Agricultural land use and asset accumulation in migrant households: The case of el salvador. J. Dev. Stud. 2010, 46, 162-189. [CrossRef]

64. Vicol, M. Potato contract farming and 'privileged spaces': Preliminary insights from rural maharashtra. DIE ERDE J. Geogr. Soc. Berl. 2014, 145, 142-147. 
65. McCarthy, J.F. Processes of inclusion and adverse incorporation: Oil palm and agrarian change in sumatra, indonesia. J. Peasant Stud. 2010, 37, 821-850. [CrossRef] [PubMed]

66. Woods, K. Cp maize Contract Farming in Shan State, Myanmar: A Regional Case of a Place-Based Corporate Agro-Feed System. 2015. Available online: https://www.iss.nl/fileadmin/ASSETS/iss/Research_and_ projects /Research_networks/LDPI/CMCP_35-_Woods.pdf (accessed on 6 June 2017).

67. Turner, M.D. Merging local and regional analyses of land-use change: The case of livestock in the sahel. Ann. Assoc. Am. Geogr. 1999, 89, 192-219. [CrossRef]

68. Bruckner, M.; Fischer, G.; Tramberend, S.; Giljum, S. Measuring telecouplings in the global land system: A review and comparative evaluation of land footprint accounting methods. Ecol. Econ. 2015, 114, 11-21. [CrossRef]

69. Prell, C.; Sun, L.; Feng, K.; He, J.; Hubacek, K. Uncovering the spatially distant feedback loops of global trade: A network and input-output approach. Sci. Total Environ. 2017, 586, 401-408. [CrossRef] [PubMed]

70. Ison, R. Systems thinking and practice for action research. In The Sage Handbook of Action Research Participative Inquiry and Practice, 2nd ed.; Reason, P.W., Bradbury, H., Eds.; Sage Publications: London, UK, 2008; pp. 139-158.

71. Richards, K.; Clifford, N. Science, systems and geomorphologies: Why less may be more. Earth Surf. Process. Landf. 2008, 33, 1323-1340. [CrossRef]

72. Checkland, P. From optimizing to learning: A development of systems thinking for the 1990s. J. Oper. Res. Soc. 1985, 36, 757-767. [CrossRef]

73. Uhrqvist, O. Seeing and Knowing the Earth as a System: An Effective History of Global Environmental Change Research as Scientific and Political Practice. Ph.D. Thesis, Linköping University, Linköping, Sweden, 2014.

74. Seitzinger, S.P.; Gaffney, O.; Brasseur, G.; Broadgate, W.; Ciais, P.; Claussen, M.; Erisman, J.W.; Kiefer, T.; Lancelot, C.; Monks, P.S.; et al. International geosphere-biosphere programme and earth system science: Three decades of co-evolution. Anthropocene 2015, 12, 3-16. [CrossRef]

75. Galvan-Miyoshi, Y.; Walker, R.; Warf, B. Land change regimes and the evolution of the maize-cattle complex in neoliberal mexico. Land 2015, 4, 754-777. [CrossRef]

76. Hauge, M.M. Mind the gap: Vietnamese rice farmers and distal markets. In Land Use Competition: Ecological, Economic and Social Perspectives; Niewöhner, J., Bruns, A., Hostert, P., Krueger, T., Nielsen, J.Ø., Haberl, H., Lauk, C., Lutz, J., Müller, D., Eds.; Springer: Cham, Switzerland, 2016; pp. 75-89.

77. Coe, N.M.; Yeung, H.W.-C. Global Production Networks: Theorizing Economic Development in an Interconnected World; Oxford University Press: Oxford, MS, USA, 2015.

78. Veldkamp, T.; Polman, N.; Reinhard, S.; Slingerland, M. From scaling to governance of the land system: Bridging ecological and economic perspectives. Ecol. Soc. 2011, 16, 1. [CrossRef]

79. Fischer-Kowalski, M.; Erb, K.-H. Core concepts and heuristics. In Social Ecology: Society-Nature Relations across Time and Space; Haberl, H., Fischer-Kowalski, M., Krausmann, F., Winiwarter, V., Eds.; Springer: Cham, Switzerland, 2016; pp. 29-61.

80. Niewöhner, J.; Bruns, A.; Haberl, H.; Hostert, P.; Krueger, T.; Lauk, C.; Lutz, J.; Müller, D.; Nielsen, J.Ø. Land use competition: Ecological, economic and social perspectives. In Land Use Competition, 1st ed.; Springer: Cham, Switzerland, 2016; Volume 6, pp. 1-17.

81. Hacking, I. Kinds of people: Moving targets. Proc. Br. Acad. 2007, 151, 285-318.

82. Vayda, A.P. Progressive contextualization: Methods for research in human ecology. Hum. Ecol. 1983, 11, 265-281. [CrossRef]

83. Walters, B.B.; Vayda, A.P. Event ecology, causal historical analysis, and human-environment research. Ann. Assoc. Am. Geogr. 2009, 99, 534-553. [CrossRef]

84. Lestrelin, G.; Castella, J.-C.; Bourgoin, J. Territorialising sustainable development: The politics of land-use planning in laos. J. Contemp. Asia 2012, 42, 581-602. [CrossRef]

85. Jerndal, R.; Rigg, J. Making space in laos: Constructing a national identity in a 'forgotten' country. Political Geogr. 1998, 17, 809-831. [CrossRef]

86. Evrard, O.; Goudineau, Y. Planned resettlement, unexpected migrations and cultural trauma in Laos. Dev. Chang. 2004, 35, 937-962. [CrossRef]

87. Rigg, J. Living with Transition in Laos: Market. Integration in Southeast Asia; Routledge: New York, NY, USA; Winnipeg, MB, Canada, 2005. 
88. Pholsena, V.; Banomyong, R. Laos: From Buffer State to Crossroads? Mekong Press: Chiang Mai, Thailand, 2006.

89. Dwyer, M.B. Turning Land into Capital. A Review of Recent Research on Land Concessions for Investments in Lao Pdr. Part 1 of 2: Existing Literature. 2007. Available online: http: / / rightslinklao.org/wp-content/uploads/downloads/2014/05/Turning-Land-into-Capital-A-review-ofrecent-research-on-land-concessions-for-investment-in-Lao-PDR-Part-1-of-2-Existing-literature-photo.pdf (accessed on 6 June 2017).

90. Thongmanivong, S.; Fujita, Y.; Phanvilay, K.; Vongvisouk, T. Agrarian transformation in Northern Laos: From swidden to rubber. Southeast Asian Stud. 2009, 47, 330-347.

91. Fox, J.; Fujita, Y.; Ngidang, D.; Peluso, N.; Potter, L.; Sakuntaladewi, N.; Sturgeon, J.; Thomas, D. Policies, political-economy, and swidden in Southeast Asia. Hum. Ecol. Interdiscip. J. 2009, 37, 305-322. [CrossRef] [PubMed]

92. Messerli, P.; Peeters, A.; Schönweger, O.; Nanhthavong, V.; Heinimann, A. Marginal land or marginal people? Analysing patterns and processes of large-scale land acquisitions in South-East Asia. In Large-Scale Land Acquisitions: Focus on South-East Asia; Gironde, C., Golay, C., Messerli, P., Eds.; Brill Nijhoff: Leiden, The Netherlands; Boston, MA, USA, 2015; Volume 6, pp. 136-171.

93. Schönweger, O.; Heinimann, A.; Epprecht, M.; Lu, J.; Thalongsengchanh, P. Concessions and Leases in the Lao PDR: Taking Stock of Land Investments; Centre for Development and Environment (CDE), University of Bern: Vientiane, Laos, 2012.

94. Sturgeon, J.C. Cross-border rubber cultivation between China and Laos: Regionalization by akha and tai rubber farmers. Singap. J. Trop. Geogr. 2013, 34, 70-85. [CrossRef]

95. Lagerqvist, Y.F. Imagining the borderlands: Contending stories of a resource frontier in muang sing. Singap. J. Trop. Geogr. 2013, 34, 57-69. [CrossRef]

96. Baird, I.G.; Vue, P. The ties that bind: The role of hmong social networks in developing small-scale rubber cultivation in Laos. Mobilities 2015, 12, 136-154. [CrossRef]

97. Higashi, S. Impacts on Regional Land Use from Investment in Banana Contract Farming by Chinese Companies-Case Studies in Oudomxay Province, Northern Laos; Mekong Watch: Vientiane, Laos, 2015; pp. 1-26.

98. Ling, S. The Use of Remittances by Circular Hmong Migrants to Chinese Banana Plantations in Bokeo, Lao PDR. Minor Dissertation, University of New England, Armidale, Australia, 2015.

99. Friis, C.; Nielsen, J.Ø. Small-scale land acquisitions, large-scale implications: Exploring the case of Chinese banana investments in Northern Laos. Land Use Policy 2016, 57, 117-129. [CrossRef]

100. FAOStat. Homepage. Available online: http:/ / www.fao.org/faostat/en/\#home (accessed on 6 June 2017).

101. High, H.; Baird, I.G.; Barney, K.; Vandergeest, P.; Shoemaker, B. Internal resettlement in laos. Crit. Asian Stud. 2009, 41, 605-620. [CrossRef]

102. Fujita, Y.; Phanvilay, K. Land and forest allocation in lao people's democratic republic: Comparison of case studies from community-based natural resource management research. Soc. Nat. Res. 2008, 21, 120-133. [CrossRef]

103. Ducourtieux, O.; Laffort, J.-R.; Sacklokham, S. Land policy and farming practices in Laos. Dev. Chang. 2005, 36, 499-526. [CrossRef]

104. Lund, C. Fragmented sovereignty: Land reform and dispossession in Laos. J. Peasant Stud. 2011, 38, 885-905. [CrossRef]

105. Vongvisouk, T.; Dwyer, M.B. Falling Rubber Prices in Northern Laos: Local Responses and Policy Option; Helvetas: Zürich, Switzerland, 2016; pp. 1-59.

106. Ordonez, N.; Seidl, M.F.; Waalwijk, C.; Drenth, A.; Kilian, A.; Thomma, B.P.H.J.; Ploetz, R.C.; Kema, G.H.J. Worse comes to worst: Bananas and panama disease-When plant and pathogen clones meet. PLoS Pathog. 2015, 11, e1005197. [CrossRef] [PubMed]

107. An. Banana trees affected by typhoon rammasun in China's Guangxi. Xinhuanet Englishnews.cn, 24 July 2014.

108. Zhong, S.; Zeng, H.C.; Jin, Z.Q. Soil microbiological and biochemical properties as affected by different long-term banana-based rotations in the tropics. Pedosphere 2015, 25, 868-877. [CrossRef]

109. Prowse, W. China's fruit imports grow 23 per cent. AsiaFruit, 25 February 2015.

110. Simeon, L.M. China lifts import ban on philippine bananas. The Philippine Star, 7 October 2016.

111. Ravindran, M.S. China's potential for economic coercion in the South China sea disputes: A comparative study of the Philippines and Vietnam. J. Curr. Southeast Asian Aff. 2013, 31, 105-132.

112. Perlez, J. Rodrigo duterte gets closer to China, and the neighbours notice. The New York Times, 24 October 2016. 
113. Phillips, T. Rodrigo duterte arrives in china with 'make friends, not war' message. The Guardian, 18 October 2016.

114. Associated-Press. Philippines to 'set aside' south chinese sea tribunal ruling to avoid imposing on Beijing. The Guardian, 17 December 2016.

115. Sturgeon, J.C. Governing minorities and development in Xishuangbanna, China: Akha and dai rubber farmers as entrepreneurs. Geoforum 2010, 41, 318-328. [CrossRef]

116. Schönweger, O.; Üllenberg, A. Foreign Direct Investment (FDI) in Land in Laos; Deutche Gesellschaft für Technische Zusammenarbeit (GTZ): Eschborn, Germany, 2009.

117. Latsaphao, K. Banana farms ordered to stop. Vientiane Times, 12 December 2016.

118. Souksakhone, V. Govt bans banana plantations. Vientiane Times, 12 November 2016.

119. Quan, Y.; Wang, C.; Yan, Y.; Wu, G.; Zhang, H. Impact of inter-basin water transfer projects on regional ecological security from a telecoupling perspective. Sustainability 2016, 8, 162. [CrossRef]

120. Leisz, S.; Rounds, E.; The An, N.; Thi Bich Yen, N.; Nguyen Bang, T.; Douangphachanh, S.; Ninchaleune, B. Telecouplings in the east-west economic corridor within borders and across. Remote Sens. 2016, 8, 1012. [CrossRef]

121. Messerli, P.; Bader, C.; Hett, C.; Epprecht, M.; Heinimann, A. Towards a spatial understanding of trade-offs in sustainable development: A meso-scale analysis of the nexus between land use, poverty, and environment in the Lao PDR. PLoS ONE 2015, 10, e0133418. [CrossRef] [PubMed]

122. Sturgeon, J.C. Introduction-Regionalization at the margins: Ethnic minority cross-border dynamics in the greater mekong subregion. Singap. J. Trop. Geogr. 2013, 34, 3-8. [CrossRef]

123. Sikor, T.; Auld, G.; Bebbington, A.J.; Benjaminsen, T.A.; Gentry, B.S.; Hunsberger, C.; Izac, A.-M.; Margulis, M.E.; Plieninger, T.; Schroeder, H.; et al. Global land governance: From territory to flow? Curr. Opin. Environ. Sustain. 2013, 5, 522-527. [CrossRef]

124. Nepstad, D.C.; McGrath, D.; Stickler, C.; Alencar, A.; Azevedo, A.; Swette, B.; Bezerra, T.; DiGiano, M.; Shimada, J.; da Motta, R.S.; et al. Slowing amazon deforestation through public policy and interventions in beef and soy supply chains. Science 2014, 344, 1118-1123. [CrossRef] [PubMed]

125. Godar, J.; Suavet, C.; Gardner, T.A.; Dawkins, E.; Meyfroidt, P. Balancing detail and scale in assessing transparency to improve the governance of agricultural commodity supply chains. Environ. Res. Lett. 2016, 11, 035015. [CrossRef]

126. Heilmayr, R.; Lambin, E.F. Impacts of nonstate, market-driven governance on chilean forests. Proc. Natl. Acad. Sci. USA 2016, 113, 2910-2915. [CrossRef] [PubMed]

127. Le Polain de Waroux, Y.; Garrett, R.D.; Heilmayr, R.; Lambin, E.F. Land-use policies and corporate investments in agriculture in the gran chaco and chiquitano. Proc. Natl. Acad. Sci. USA 2016, 113, 4021-4026. [CrossRef] [PubMed]

128. Haberl, H.; Mbow, C.; Deng, X.; Irwin, E.G.; Kerr, S.; Kuemmerle, T.; Mertz, O.; Meyfroidt, P.; Turner, B.L. Finite land resources and competition. In Rethinking Global Land Use in an Urban Era; Seto, K.C., Reenberg, A., Eds.; MIT Press: Cambridge, MA, USA, 2014; pp. 35-70.

129. Baumann, M.; Kuemmerle, T. The impacts of warfare and armed conflict on land systems. J. Land Use Sci. 2016, 11, 672-688. [CrossRef]

130. Preston, B.L.; King, A.W.; Ernst, K.M.; Absar, S.M.; Nair, S.S.; Parish, E.S. Scale and the representation of human agency in the modeling of agroecosystems. Curr. Opin. Environ. Sustain. 2015, 14, 239-249. [CrossRef]

131. Verburg, P.H. The representation of human-environment interactions in land change research and modelling. In Understanding Society and Natural Resources: Forging New Strands of Integration across the Social Sciences; Springer: Dordrecht, The Netherlands, 2014; pp. 161-177.

132. Howitt, R. "A world in a grain of sand": Towards a reconceptualisation of geographical scale. Aust. Geogr. 1993, 24, 33-44. [CrossRef]

(C) 2017 by the authors. Licensee MDPI, Basel, Switzerland. This article is an open access article distributed under the terms and conditions of the Creative Commons Attribution (CC BY) license (http:/ / creativecommons.org/licenses/by/4.0/). 